DOI https://doi.org/10.36059/978-966-397-145-2/147-169

\title{
ANTHROPOLOGICAL DIMENSION OF THE FORMS OF FREEDOM
}

\section{Shypunov H. V., Andrushchenko T. V.}

\section{INTRODUCTION}

At its current stage of development, Ukrainian society is in the process of systematic changes, which in such situations are inevitably followed by the confrontation of social ideals and destruction of stereotypes of thinking that radically change the idea of a human, the life purpose, place and role in society.

The freedom as a phenomenon, an idea, a value and an ideal is one the most important aspects of human-being. The representatives of different historical periods have come to interpret this issue in their own peculiar way. The development of modern Western civilization is largely based on the understanding of freedom that has emerged in different currents of philosophical thinking over the last centuries.

Understanding of the phenomenon of freedom is one of those problems in philosophy that never loses its relevance, because it is closely linked to the problem of human; it defines itself differently throughout its history, motivating us to think about the essence of ourselves and to create the various interpretations of the phrase "homo libertus". The question of freedom also arises for philosophers in ever new aspects.

The conditions for actualization of the outlined issue are the following. From the second half of the XX century, philosophical thought has referred to the problems of new forms of non-freedom arising from scientific and technological progress and increasing levels of informatization of society. It is also about increasing the ideologization of consciousness and the imposition of standardized 
ways of behaviours and thinking caused by the increasing role of mass culture.

The widespread dissemination of pseudo-liberal ideas provokes the all-permissiveness of forms of individual self-realization in social and cultural life. Such "liberalism" transforms into nihilism regarding the socio-cultural sphere of human being and the dominance of the "cynical mind".

The dependence of the theoretical level of modern researches on the understanding of the achievements and specifics of modern philosophy in general and its solution to particular philosophical problems forces to appeal to the historical heritage of European and national philosophy, their tendencies of development as a holistic, systematic display of the contradictory process of the formation of the idea of freedom and its historical forms. Thereby, a comprehensive analysis of the epistemological and social dimensions of freedom in modern philosophy requires thorough scientific research. This is also determined by the fact that ideas of freedom are significant components in the system of knowledge about society and its formation. They play a significant role in determining the goals of the historical activity of people in various spheres of society: politics, culture and science.

\section{Political Anthropology as a Paradigm of Political and Philosophical Reflection}

The analysis of freedom is deeply connected with the definition of personal boundaries and forms of this phenomenon. The freedom receives a special limitation in political forms of its definition, thus, acting as a criterion and the ascending principle of determining all forms of freedom in a particular society and in real historical circumstances.

Political anthropology as a concept and as phenomenon is rather polyphonic, but its establishment as a separate branch of political knowledge was preceded by significant shifts in the system of so-called "anthropological reflection". The subject of the latter has traditionally 
been not only the issues of ideological and psychological states of mankind, but also the human-being as a basis for the universe in general. To paraphrase the outstanding thinker of the early Renaissance period M. Kuzanskyi, the essence of an anthropological ideology can be defined by the principle of causa sui, i.e., a human as a self-determining entity. Unlike the phenomena of nature, which are determined by the action of external factors, a human himself determines his goals in life and achieves goals through means, which, again, he chooses to his taste and discretion.

Therefore, one can speak of the existence of an anthropological paradigm as a principle of political existence, which determines the human-being as a creative unit in social time and space. According to that paradigm, a human assumes responsibility for its behaviours and actions not blaming external circumstances. Political anthropology deepens into the traditions of political practices of different nations, analyses the technologies of political interactions of different political subjects, and, most importantly, it creates a fundamentally new discourse in the study of political realities, a discourse focused on the human primacy in politics.

Initially, the object of the political and anthropological tendency was only the analysis of the political processes of archaic societies, especially colonised ones. However, the scope of research has substantially expanded since then, and today anthropology is actively covering the research of modern political institutions and processes. At the centre of political anthropology is a person - a carrier of political ideas, consciousness, ethical values and behaviour.

Before switching to purely scientific problems of the reflection of political anthropology, we should note that its appearance was preceded by a revolution of consciousness from a worldview standpoint, which delineated civilizational boundaries of entire states and nations, thereby having a substantial influence on their political history and political being itself. Without it, political anthropology as a scientific field - i.e., 
a product of a much later intellectual and spiritual production - would have been impossible. As an additional remark, this process known as "anthropologising" of knowledge and culture in general, is still ongoing.

The appeal to a person as the centre of the political world is caused by numerous factors. If we were to talk about the socio-cultural foundations of this process, we should firstly emphasize the liberalindividualistic traditions, which take the origins from primitive capitalism, the period of the early bourgeois revolutions, and Protestant ethics. At the centre of these processes was human freedom as the supreme value and norm of a new style of life, a new historical formation.

Summarizing the contribution made by Western European civilization to the world culture in terms of humanistic values, the discovery of human-being as a phenomenon is probably the most important achievement worthy not only of artistic idealization, but above all of the politics of creating certain and social principles for its selfrealization. In this context, we mean not the individuality of a biological species, but a social individuality, which realises itself through economic, social, spiritual, and, finally, political freedom. This discovery could not have been spontaneous, and it may not be designated solely to the Renaissance, although it was in this period that the "anthropological turn" was founded by providing, probably, the largest intellectual input. However, the ancient ideal of aesthetic harmony of the spiritual and corporal, and Roman private law, which stood on the protection of personal interests of human, along with the medieval university education including the Christian scholastics, which trained the logical craft of thinking - all of the above are components of the grandeur event, which was finally the discovery of a human personality as a higher value and calculus of the human development and historical progress altogether.

The genesis of Eastern European civilization, with all the conditionality of such division, was somewhat different, although, objectively (and this should be admitted), it exists at least on the level of 
confessional, mental and cultural factors. We should not once again blame the unfortunate historical destiny, at least in the instance of that destructive and tragic domination of Mongols and Tatars, which resulted in division of European civilisation to its Western and Eastern segments. We think that the issue here is that the Eastern European nations held the rather archaic elements of social relations, where the principal component was not the individual owner, free intellectual, hired worker or unemployed, but a collective subject - at first, it was family and community, later - social group, strata, class etc., lines between which had always been very clear and almost cast-like, was the in their geoeconomics systems for far too long. Compared to the European sociocultural traditions based on the values of individual freedom, Eastern European and in particular Ukrainian traditions are based mainly on social, i.e., group or collective values. If European philosophical and political thought, starting from the XVI - XVII centuries, is concerned with the problems of freedom of society, and in particular the freedom of a human, then Ukrainian studies, with rare exceptions, concern mainly social or national ideologies where personality has a secondary role.

Therefore, there are reasons to speak about two fundamental paradigms of ideological and political order. This, on the one hand, is a paradigm that we define as "anthropological" since human and human freedom is in the centre. And, on the other hand, it is about the "collectivist" paradigm, which is differentiated into "sociocentric" and "natiocentric" sublevels within this paradigm.

Of course, the abovementioned differences are not absolute, but rather relative. This is because the Western European civilisation was not missing out on societal utopias, doctrines and ideologues, similarly to the Eastern European and, particularly, Ukrainian was not lacking certain anthropological manifestations and inclinations of philosophical, historical and political thinking. But the difference lies in the fact that on the territory of the Western European civilisation the values if individual freedom, namely, liberal democracy in its different forms, had finally 
won, whereas on the Eastern European territories, including Ukrainian, the situation came out to the contrary - the primary values were those of corporate collectivism, regardless of under which mottos and flags - be it socialist, communist, fascist and nationalist. Such differences in the structures of political mentality and paradigmal thinking led to different development trends in political and anthropological systems in the West and the East of European civilisation.

With regard to the different directions of anthropological knowledge, it is obvious that they differ significantly from one another. For example, political anthropology is based on the standpoint of human life and tries to explain the regularities of formation and functioning of power in society through political participation as a special form of human life and activity.

Theological anthropology is also based on the value of humanbeing, substantiating its eternity and immutability as bestowed by God. The philosophical aspirations of modern theology are based on the principles of pluralism rather than monism, as it was before. Modern theological anthropology explains the essence of a human as a partner of God and does not perceive her as a stand-alone unit.

With regard to political and philosophical anthropology, their correlation is based not on ideology, but on methodological grounds. According to B. Markov's definition, philosophical anthropology deals with the most important subject of being, where human plays a central role. It reveals the humanity in human and proves its significance in our cruel world of struggle for survival. For this purpose, it describes a human, not as an idealized concept but proceeds from a realistic recognition of human's desires, which some moralists consider something insignificant. It must show the real person, destroying all the myth $^{1}$. Based on the human's place in the world, philosophical

${ }^{1}$ Марков Б. Философская антропология. Очерки истории и теории. СанктПетербург, 1997. С. 12-13. 
anthropology raises the question of the meaning of its existence, putting it in the projection of humanistic norms and values that adjust the cruelty of the struggle for existence through empathy, partnership and love to each other. In addressing this issue, she seeks to discover how human has produced and continue to produce humanity in oneself and how it became the creator and creation of its own culture ${ }^{2}$.

Since in today's context the problem of the interrelation of a human and politics was placed on the background, it is worth paying attention to the problems of general political science, ethnopolitics and geopolitics regarding political anthropology. The philosophical reason for changing the direction of political discourse toward political anthropology can be considered a change from the rationalist paradigm to an existential one, i.e. the basis of the first was the epistemological situation in the framework of the relation "matter-consciousness", the second one was based on the relation "human-world".

The analysis of the national literature on political science regarding the correlation between human and politics shows that a human continues to be traditionally explored from two points of view: as a part of society and as an individual. From the first point of view, it is a tendency according to which human is obeyed to society, serves and exists for society. The second focuses its attention on the individual, on the process of his or her integration with politics within society.

Western individualism and the political anthropology formed on its basis are devoid of the features of abstract humanism, as well as of the non-alternative ideology to which totalitarian regimes and societies fall for.

The research of the issue "human - politics" in the national humanitarian studies was based and is still based on the establishment of state totalitarianism, both in theory and in practice. This is very well

2 Марков Б. Философская антропология. Очерки истории и теории. СанктПетербург, 1997. С. 232. 
proven and demonstrated by L. Klimanska in the analysis devoted to the phenomenon of the "new human" of the Soviet model ${ }^{3}$. Nowadays there is an urgent need to introduce a fundamentally new concept of civilization progress based on the principles of causal connection between human and society, where politics is a legal mean of transformation of the individual potentials of everyone into the sphere of public life, and, furthermore, person does not become a hostage of a decision made once and for all.

Considering politics only like the sphere of life and activity of collective individuals, we leave beyond the political reality the place and the role of a person in politics. Recently, however, some signs and manifestations of anthropologization can be found, at least in the interpretation of politics as a phenomenon which is a product of human consciousness, activity and creativity, caused by various motives and factors, which are first and foremost related to a human's personal qualities: "Politics is a product of the conscious and random, often arbitrary people's activity, their efforts of will, driven by their particular interests" 4 .

Based on the above mentioned, we can outline the main issues of the political anthropology for the formation and development of modern national political and anthropological study, it is the question of conceptual correlation and ideology of citizens and the question of their position regarding life and politics; the issue of overcoming the traditional alienation of the individual and the power; the issue of representation by the authorities not only of the general, but also of social, corporate, and most importantly - personal interests of a human.

From our point of view, in order to make a kind of "anthropological revolution" in our political consciousness, we need to

3 Кліманська Л. Політична антропологія. Людина та іiї дійсність: філософсько-антропологічні дослідження. Львів-Одеса, 1997. С. 170-174.

${ }^{4}$ Рябов С., Томенко М. Основи теорії політики. Київ, 1996. С. 7. 
go beyond understanding of the politics as a purely social phenomenon and take up politics as a creative characteristic of human being. This will give the opportunity to use the motives and interests of a human, who ultimately create political history. Then, the political goals, aims and instruments will be relevant to the individual capacities, not "political armies", which have to be mobilized for "historical achievements", headed by a "cult personality".

Thanks to the anthropologization of political reflection, new horizons of acceptance of human as individual are opened, and the human is regarded as generally recognized and acquired the norms and values of social legitimacy. Among such horizons is an analysis of the conditions and patterns of the transformation of the creative potentials of a politician into a political power.

The abovementioned transformation has always taken place in the past, but it was hardly controlled by society, since the customs and traditions that contributed to securing the institute of dynastic right to political power or the control of formal will by the totalitarian regime remained the determining factor. The authoritarian, and even more the totalitarian, regimes do not assume social control over power since the politics stands aside from a society and a human and it becomes owned by a dictator or a group. And only the democratic regime gives the right and the possibility of such control, which naturally raises the demands for political leadership as a social and at the same time personal phenomenon in politics.

To disclose its own content, political anthropology uses the following approaches to the object and subject of its research: civilizational, axiological, cultural, and sociological. The core factor here is the civilizational approach. The essence of this approach is to consider the process of transformation of power into politics as such that does not occur in the building-up of power, the transformation nature of which is determined through the opposition "lower-higher", "worse-better", but the process in which every person through self- 
determination and self-affirmation recreated these oppositions of power for itself, "discovered them in a very new way, enriched them with something of its own, with national and its own existential experience" .

Political anthropology uses sociological, cultural, axiological, psychological and mathematical methods as a substantive basis. The theoretical system of political and anthropological knowledge is based on a system of principles, through which it acquires logical consistency and completeness. The system of principles should include the principle of complementarity of anthropological knowledge. Modern anthropological study in its nature, form and content is extremely diverse, which implies its consistency. This diversity is quite complicated and contradictory correlates with the specificity of different anthropological concepts. However, when formulating the principles of political anthropology, we must take into account the fact that any anthropological concepts are always have something in common and interconnected. The second principle is the principle of humanism (anthropocentrism). Its essence lies in the orientation of the research of political anthropology on a human, his relation to the world, to his own life and to himself as a human-being.

Therefore, political anthropology is not only a concept of substantiation of the primacy of individual in politics, which the systems of political overlook - liberalism, democracy and, to a certain extent, even anarchism etc. - base upon. In the genesis of political anthropology, we can define those directions, which: a) tried to make the essence of human to vital characteristics as basis for immoralism; b) tried to use the same theoretical foundations of evolutionary theory dedicated to the world of nature, but not to the world of human society to substantiate the anthropology itself in politics.

${ }^{5}$ Бойченко І. Нелінійна соціальна філософія: цивілізація як монада історії. Філософські студії Київського університету. 1995. Вип. 1. С. 84. 
One way or another, anthropological ideas were manifested by the national political thinkers and activists. To make sure of that, it is worth analysing the peculiarities of the national political and anthropological discourse on the examples of the famous political thinkers, who touched upon this problem.

\section{The Issue of Human Freedom in Ukrainian Political and Philosophical Sciences}

Modern Ukrainian national movement founded in the midXIX century originally had a strong cultural and educational character. Nonetheless, certain moral and ethical principles, which came around political ideals were organic components of this movement. Thus, it was no surprise that the movement, originally founded by the Cyril and Methodius Society, had soon become a frankly political one, since its aim was restoration of Ukrainian statehood.

One of the first researchers of the Ukrainian national movement was M. Drahomanov. He noted a few characteristic features of this phenomenon emphasizing on the decisive role of T. Shevchenko in the origination of Ukrainian socio-political thought ${ }^{6}$. The appearance of the Shevchenko's discourse connected with the idea of collective freedom was a logical outcome, which is confirmed in the ideological foundations of the Cyril and Methodius Society. Despite the fact that it had connected people from different social states, the unifying link was a protest against national, social and economic situation of the Ukrainian people. This served as a ground for formation of the respective complex of moral and ethical values of the forefront Ukrainian intelligence, which was fuelled by the spirit of sacrifice and asceticism in the authoritarian Russian Empire. The core political idea of the Cyril and

${ }^{6}$ Драгоманов М. Антракт з історії українофільства (1863-1872). Вибране / Драгоманов М. Київ, 1991. С. 256. 
Methodius Society was independence and establishment of a sovereign Ukrainian state.

Institutes of the social solidarity and civilised collectivism, or, quoting M. Drahomanov, "human unions", were viewed by Drahomanov as essential part of the individual freedom as a principle of moral and ethical code. By Drahomanov, the ethics of freedom acquires a general notion of social doctrine, - a human voluntarily, at his own risk, chooses the form of cooperative association, which corresponds his interests and life needs.

Forecasting revolutionary movements in Russia made Drahomanov actively critiquing the cons of Russian revolutionary environment. In "Autobiography”, M. Drahomanov concluded, which of the most characterising features of the Russian revolutionaries he radically condemned: "Aside from their great Russian centralism and anti-cultural trends, nationalist illusions, Machiavellian means... I was different from them in accepting political homicide or, as they said, "terror" as a principal of revolutionary struggle..."?

M. Drahomanov emphasised that the activists of Ukrainian movement had substantially better conditions for achieving the goals of their liberation movement, since they had something "to stand upon" in the traditions and historical memory of their own people. At the same time, M. Drahomanov had a clear understanding that despite positive historical, moral and cultural preconditions, Ukrainians had plenty of their own imperfections. Moreover, the impact of imperial culture had been far from bringing "civilisation" to Ukraine.

To summarise, M. Drahomanov's emphasis on the unacceptability of ignoring moral norms of a political activist, which fights for progress and truly desires to achieve high noble goals, has been an important part of his theoretical legacy.

${ }^{7}$ Драгоманов М. Автобіографія. Київ, 1917. С. 42. 
In the opinion of several experts of Ukrainian political history, in the 70s-80s of the XIX century "socialisation" of the new generation of intelligence, which undertook the highly moral mission of Ukrainian restoration, has been mostly completed. The leader of this generation was I. Franko. After M. Drahomanov, the Kamenyar (stone breaker) became the second figure, whose political ideology tried to connect to philosophical, political and worldview trends - personalist and collectivistic.

By his political outlook I. Franko, following the footsteps of T. Shevchenko, was largely an heir of a romantic direction of the philosophy of history, in particular, its messianic part. However, we can undoubtedly note that, being at the crossroad of different ideological influences and due to the fact of national being of Ukrainian people, I. Franko as a political thinker bears the most essential moral contradictions. Of course, we are talking about Marxism. Paying homage to its "philosophical conscience" of the early years, he followed the footsteps of those critics of Marxism, who mistakenly derived utopianism of its social ideal from the outlook principles of the materialistic theory. Paying tribute to the role of material and economic factors in human history, I. Franko did not share the approach of the representatives of "historic fatalism", as he used to characterise Marxism, but rather preferred human proactiveness, freedom, ideals per se: "When the ideal-life of the individual has to be recognised as a driving force in material production, the one forcing people to discoveries, research, extremely hard work, service, unions etc., then not less, but even more important is the ideal in social and political life" ${ }^{8}$.

Nonetheless, it may not be omitted that I. Franko's drift from Marxism was a result of the new features in his outlook, which may be conditionally defined as a kind of ethical personalism. It is the lack of

${ }^{8}$ Франко I. Поза межами можливого. Що таке поступ? Одвертий лист до гал[ицької] української молодежі. Київ, 2012. С. 32. 
the factor of individual will that compromises the social perspective in Marxism, with the latter deriving from the dogmatised theory of "historical fatalism". Due to Kamenyar, in this theory "the almighty power of the state would be a horrible burden of every individual man" 9 . It is worth adding that ideological substantiation of the regime by the accentuated yet simplified world landscape was confusing I. Franko in the Marxism the most - Marxism, by Franko, "contains the ready forms for explaining the most complicated historical notions: religion is a creation of the bourgeoisie, nationalities are creations of the bourgeoisie, national states are creations of the bourgeoisie etc" ${ }^{10}$.

Summarising the principal moral and political ideals and views of I. Franko, we may state that he was in constant dialogue with his own conscience dived into the excitement and "belief in Western European ideals". By I. Franko, the real progress is based upon "the first principle of any social life - respect to human, its blood interests, its neutral, inalienable rights" $"$.

At the beginning of the $\mathrm{XX}$ century the political thought was enriched by the development and substantiation of a direction based upon a conservative paradigm. The most notable representative of this direction in Ukraine in the beginning of the XX century was V. Lypynskyi.

Being an uncompromised opponent of the socialistic ideas, he was successively guided by the thesis that a true statehood may be reached only on the principles of classic conservatism and traditionalism, which are allegedly inherent to Ukrainian national self-consciousness specifically. In this regard, V. Lypynskyi notes that true national ideals

9 Франко І. Поза межами можливого. Що таке поступ? Одвертий лист до гал[ицької] української молодежі. Київ, 2012. С. 67.

${ }^{10}$ Франко I. Ukraina irredenta. Жите і слово. 1895. Т. IV., Ч. 6. С. 479.

11 Франко І. Передмова до збірки поезій "Мій Ізмарагд”. Давнє $і$ нове. / Франко І. Львів, 1911. С. 9. 
are foremost based upon the general human values - work ethics, moral grounds etc ${ }^{12}$.

The core problem for V. Lypynskyi was determining the reasons of failure of "liberation conquest" of 1917-1920 for the Ukrainian statehood and development the concept of its restoration in the future. As to such concept, this is reflected in Lypynskyi's political opus magnum - "Letters to brothers-farmers", published in Vienna in 1926.

Undoubtedly, the thinker's political idea was Ukrainian statehood, establishment of which he viewed from the standpoint of an originally interpreted elite theory. Particularly, touching upon such important aspect of the problem as stable and sustainable existence of Ukrainian national organism, V. Lypynskyi thought that the constitutional monarchy is the most acceptable model for Ukraine. However, such model itself does not solve all of the problems, thus, one of the most important conditions Lypynskyi mentioned a balance of interests between those who govern and those who are governed "to avoid:

a) anarchy and boorishness from advantage of the people over state;

b) stagnation and slavery from an unlimited power of state over the people" 13 .

"Classocracy" holds a central place in Lypynskyi's concept, by which he means "the strongest, the most capable and influential people in their classes", noting that "Ukrainian State can only be achieved through classocracy: political cooperation of authoritative class leaders, limited in their desire to the most power for their class, obedience to outof-class state-national law and preserving this law by one Hetman State

12 Шморгун О. Україна: Шлях відродження (економіка, політика, культура). Київ,1994. С. 126-127.

13 Липинський В. Листи до братів хліборобів. Про ідею і організацію українського монархізму. Київ, 1995. С. 36. 
Power" $"$. The political discourse here is based solely around such concepts as: "class", "power", "state law" etc. These are the notions, which orient to collective yet rather abstract notions, where sole man may get lost.

Political anthropology of $\mathrm{V}$. Lypynskyi is based upon the historical-civilisational and geocultural context. From these foundations, he builds his reflection on two types of cultures, which struggle has had a substantial impact on historical and political destiny of Ukraine. It is a struggle between the settled breadmaking and nomadic steppe cultures. Focusing on this alternative, he raises the problem to the level of cultural-anthropological and geopolitical scale, appealing not only to the consciousness, but to emotions too: "Is our long-suffering history, from the beginning of days until now, actually orbiting around the one and only fatal question: who - the nomads or - the breadmaker - win within us? Isn't it our biggest national tragedy that so far neither of them has actually won?"15.

Substantial attention in his "Letters" is paid to the analysis of difficulties on the way to creation of the independent Ukrainian state: "If only all of the Ukrainian saw that mighty rock that they wanted to move, they would understand that their irritation comes from the unlimited complexity of this task. Once they understood that, they would have quarrelled less amongst themselves, would unite in a tighter community, and would like to understand the nature of this rock much better" ${ }^{316}$. This is a rather typical moment of an anthropological discourse of a conservative political thinker, since, touching upon human aspects only, he sees them only in conjunction with "serving", "duty", "sacrifice" of

14 Липинський В. Листи до братів хліборобів. Про ідею і організацію українського монархізму. Київ, 1995. С. 36.

15 Липинський В. Листи до братів хліборобів. Про ідею і організацію українського монархізму. Київ, 1995. С. 172-175.

16 Липинський В. Листи до братів хліборобів. Про ідею і організацію українського монархізму. Київ, 1995. С. 11. 
its kind, which is a persuasive evidence that Ukrainian conservativism eliminated individuality as an autonomous and sovereign being of a political process.

Finally, V. Lypynskyi concluded: "We fought ourselves. National leaders did not create ideas, beliefs, legends of one and only Ukraine, which would unite free and independent Ukraine; they did not fight for such an idea, so it is understandable why such Ukraine was not able to be created, to obtain real, live shapes"17. However, the question is not in the idea, which is unlikely to appear at all, even less has the chance for success in class- and nationally-divided society. Imposing any idea from above, if such idea is not based on human needs and interest, is destined to lose. The only resource, which the social and national consensus can be based upon, is the resource oh human freedom, which, unfortunately, is unnecessary in the given circumstances.

The ideological follower of the historic concepts of $\mathrm{M}$. Drahomanov was M. Hrushevskyi, who wrote: "I was raised in strict traditions of radical Ukrainian national tradition, which led its ideology from the Cyril and Methodius Society and was firm that the conflicts between the state and the people is a liability of the state, because the interest of the working people - is the highest law of any social organisation, and when the people does not feel themselves good in such state, it is the right of the people to deal with such state" ${ }^{18}$.

The Historiosophy of M. Hrushevskyi's magnum opus - "The History of Ukraine-Rus" - is based on three key elements: population, territory and state. Social - and, thus, moral and ethical - grounds of Ukrainian people are, by M. Hrushevskyi, "country-centric". He wrote: "Throughout the whole century Ukrainian people and Ukrainian villagers have become synonyms. Since all other classes betrayed their

17 Липинський В. Листи до братів хліборобів. Про ідею і організацію українського монархізму. Київ, 1995. С. 14.

${ }^{18}$ Грушевський М. Борітеся - Поборете. Відень, 1920. 64 с. С. 12. 
nationality, all the material for the national construction had been drawn from it" ${ }^{19}$.

Similarly to M. Drahomanov, M. Hrushevskyi believed that political state is eviler than a positive factor in formation of social life, where the focus should be on the rights of a single person - a part of the mass. He defined the meaning of the state as a catalyst, which formed a principally passive mass, throwing here state, political, cultural, economic and legal structures. If those structures grew on the "national soil" and "responded to national needs", then "they were accepted as own, if not, then masses rebelled against such structures" 20.

As M. Drahomanov's student, M. Hrushevskyi was influenced by the idea of "societal socialism", which is confirmed by the political biography of the historian leading the Ukrainian Central Council. However, contrary to radical socialistic movements (particularly, bolshevism), he substantiated ways and methods of changes and transformations in the society under a reformist scenario, which was more likely to fit with the European traditions of socialism rather than those formed on a national soil. Therefore, M. Hrushevskyi had his own concept of uniting social and national questions, which was based on evolutionism of the social development and political reforms, on one hand, with the subsidiary role of the state factor, on the other hand.

Highlighting our problematic would have been incomplete without one of the most prominent ideologists of Ukrainian integral nationalism - D. Dontsov. In his primary work "Nationalism" (1926) he outlines his interpretation of the "national voluntarism" philosophy, with the theoretical foundations drawn out from ideas on the state of F. Nietzsche. Similarly to the letter, Dontsov's theory was based on the

${ }^{19}$ Грушевський М. Підстави великої України. Вибрані пращуі. / Грушевський М. Нью-Йорк, 1960. С. 90.

${ }^{20}$ Грушевський М. Вступний виклад 3 давньої історії Русі, виголошений у Львівському університеті 30 вересня 1894 р. Твори: У 50 т. Т. 1. / Грушевський М. Львів: Світ, 2002. С. 149. 
concept of will. Dontsov's interpretation of will is based on the notion of "unquenchable emotionality" - "desire to life without sanctions of being acquitted, without reeling",21.

Fanatism and amorality were probably the most important requisites of the "true nationalism" for their followers. By D. Dontsov, the national idea must have been "amoral" and, respectively, not governed by the generally accepted human principles. This amoral policy must be realised by a fanatic human being, who "discovered his truth as declared, general, the one which must be accepted by others". This explains the aggressiveness and intolerance to other views: "Firm belief in declarations, [...] unlimited hatred to everything, which stands in their way - this is the amount of feelings, which covers every true revolutionary, true fanatic - from the ends of his limbs and the nature of thoughts protected by him" 22 .

From the anthropological standpoint, D. Dontsov's attempt to describe psychoanthropological types of the representatives of the elites basing respective reflections on the racial anthropology materials is rather interesting. Stemming from the division of nations on ruling and obedient, Dontsov defines six racial-psychological types. The highest in this hierarchy is Normandic type with the typical for him qualities of winner and power-loving representative of the highest cast among the races. The second type, accordingly, is Pontius, Mediterranean and to the lowest - Dinarian and Ostian human types ${ }^{23}$. Characterising Ostian as a representative of Ukrainian democratic class, Dontsov provides him only with negative (from moral, ethical and psychological points of view) features: "Such values as heroism, generosity, honour is unfamiliar to the Ostian", - says Dontsov ${ }^{24}$. Therefore, D. Dontsov lies his hopes of implementation of political ideal fully on a new racial type

\footnotetext{
21 Донцов Д. Націоналізм. Лондон, 1966. С. 223.

22 Донцов Д. Націоналізм. Лондон, 1966. С. 228.

23 Донцов Д. Дух нашої давнини. Прага, 1943. С. 154.

${ }^{24}$ Донцов Д. Дух нашої давнини. Прага, 1943. С. 96.
} 
of human, foreseeing its coming in the future: "New resurrected race of leaders, strong and firm, decisive and wilful, strong in spirit, hungry for power - will lead the nation out of poverty" ${ }^{\prime 2}$. However, in this opus D. Dontsov did not give an answer to the question - which way should Ukrainian nation take to reach its state independence.

Finally, we shall conclude that the ideology of "firm nationalism" of D. Dontsov had a political impact on formation of political outlook, moral and ethical foundation of Ukrainian nationalistic movement in 1920-1930s, especially in Halychyna. However, the inherent destructive tendency and lack of creative ideas, which wold procure establishment of sovereign Ukraine, made this period "unproductive" in this context. "Integral nationalism" did not become the ideology of the Ukrainian liberation movement for any lengthy period.

\section{CONCLUSIONS}

Therefore, from the standpoint of political anthropology, human essence lies within oneself, in one's individual corporal being, in one's ability and capacity to create both social and personal life, establish connections, change them according to own free will and desire, choose a better and more appropriate life. This explains the main purpose of the political anthropology, which is a development of foundations, grounds for delimiting exercise of power and politics in human personal life. Ignoring conclusions of political anthropology opens the way to unlimited experiments over human freedom, using it for whatever absurd goals and ideas, which view a person only as a mean, but not as a "goal as it is" (I. Kant). In this respect, XX century proved to be more than persuasive evidence of what can be done not only to a human, but to societies and states, which fail to find an adequate understanding and application of Kantian anthropological postulate. After all, from anthropological standpoint, civilizational progress of humankind - from

\footnotetext{
${ }^{25}$ Донцов Д. Дух нашої давнини. Прага, 1943. С. 96.
} 
the primal communal system, slave-owning and feudalism to various stages of capitalism can be characterised as a development in a way of increasing limits and opportunities of human freedom.

As to the problematic of human freedom in Ukrainian political and philosophical studies, it is worth mentioning that the social studies defines key topics in Ukrainian social and political thinking as those, which are first and foremost oriented on the collectivist ideas and values, namely, nationalism, socialism, communism and fascism. As to the other values, which are based on individualistic values, they, although they were not unfamiliar to standalone intellectuals, did not have a leading position. Generally, our past reference only to "three sources and three components of Marxism" with an addition of revolutionary-democratic ideology in a place, where we spoke about the history of national philosophy, was a purposeful narrowing of thinking, limitation of the scope of research on this area of studies.

Here, we talk primarily about the historical evolution of "selfacknowledgement of Ukrainian ethnos as a united community", i.e., an intellectual tradition founded back in the 40s of XIX century by the members of Cyril and Methodius Society and interrupted somewhere on the edge of 1930s. This is something that in the terminology of the classical philosophy is called "national idea". Restoration, but more importantly - critical and creative rethinking of interrupted historical tradition will be beneficial for overcoming of the protracted spiritual crisis of the Ukrainian society, as well for restoration of the longdisturbed integrity of the Ukrainian political culture.

\section{SUMMARY}

This article considers anthropological dimensions of the forms of freedom in European political, philosophical and social studies. Specifics of the political anthropology as a paradigm of political and philosophical reflection has been clarified. Input of the Western and 
Eastern European civilisations into the development of anthropology has been substantiated. The author demonstrated that reference to human as center of political world is inherent tot Western tradition, whereas Eastern European tradition (including national) puts collective in the core of its studies. The author also defined key tendencies of the anthropological knowledge. Cooperation of human and politics, within which a person is seen in two dimensions - as a human and as a member of the society - had been analysed. The author also clarified the essence of the problem of human freedom in Ukrainian political and philosophical studies. Orientation of Ukrainian social and political thought of XIX - XX centuries mainly on collectivist ideas and values, where a standalone human usually has a secondary role, has also been defined.

\section{REFERENCES}

1. Бойченко I. Нелінійна соціальна філософія: цивілізація як монада історії. Філософські студї Київського університету. 1995. Вип. 1. С. 61-90.

2. Грушевський М. Борітеся - Поборете. Відень, 1920. 64 с.

3. Грушевський М. Вступний виклад з давньої історії Русі, виголошений у Львівському університеті 30 вересня 1894 р. Твори: У 50 т. Т. 1. / Грушевський М. Львів: Світ, 2002. С. 135-149.

4. Грушевський М. Підстави великої України. Вибрані працฺі / Грушевський М. Нью-Йорк, 1960. С. 90-113.

5. Донцов Д. Дух нашої давнини. Прага, 1943. 426 с.

6. Донцов Д. Націоналізм. Лондон, 1966. 256 с.

7. Драгоманов М. Автобіографія. Київ, 1917. 59 с.

8. Драгоманов М. Антракт з історії українофільства (18631872). Вибране. / Драгоманов М. Київ, 1991. С. 239-286.

9. Кліманська Л. Політична антропологія. Людина ma ї̈ дійсність: філософсько-антропологічні дослідження. Львів-Одеса, 1997. C. $170-174$. 
10.Липинський В. Листи до братів хліборобів. Про ідею і організацію українського монархізму. Київ, 1995. 470 с.

11.Марков Б. Философская антропология. Очерки истории и теории. Санкт-Петербург, 1997. 381 с.

12.Рябов С., Томенко М. Основи теорії політики. Київ, 1996. 192 c.

13.Франко I. Поза межами можливого. Що таке поступ? Одвертий лист до гал[ицької] української молодежі. Київ, 2012. $80 \mathrm{c}$.

14.Франко I. Передмова до збірки поезій "Мій Ізмарагд". Давнє і нове. / Франко І. Львів, 1911. 268 с.

15.Франко I. Ukraina irredenta. Жите і слово. 1895. Т. IV., Ч. 6. C. 471-483.

16.Шморгун О. Україна: Шлях відродження (економіка, політика, культура). Київ, 1994. 208 с.

\section{Information about the author: Shypunov H. V.,}

Doctor of Political Sciences, Associate Professor, Department of Theory and History of Political Science, Ivan Franko Lviv National University 1, Universytetska str., Lviv, 79000, Ukraine Andrushchenko T. V.,

Doctor of Political Sciences, Professor, Department of Political Psychology and Socio-Legal Technologies,

National Pedagogical Dragomanov University 9, Pyrohova str., Kyiv, 01601, Ukraine 